Gut, 1977, 18, 827-832

\title{
Maximum acid output to graded doses of pentagastrin and its relation to parietal cell mass in Chinese patients with duodenal ulcer
}

\author{
F. C. Y. CHENG, S. K. LAM, AND G. B. ONG \\ From the Departments of Surgery and Medicine, University of Hong Kong, \\ Queen Mary Hospital, Hong Kong
}

SUMMARY In groups of Chinese patients with duodenal ulcer and controls, increasing the dose of pentagastrin from the standard dose of $6 \mathrm{ug} / \mathrm{kg}$ to either $9 \mathrm{ug} / \mathrm{kg}$ or $12 \mathrm{ug} / \mathrm{kg}$ did not result in any change in the maximum acid output (MAO). Comparison of the MAO thus obtained with that reported in series of Occidental subjects suggested that the Chinese subjects had smaller MAO. Using the method of Card and Marks (1960), the parietal cells of resected stomachs were counted in a group of Chinese patients with duodenal ulcer. It was found that the parietal cell mass (PCM) correlated with the MAO, both PCM and MAO were significantly smaller in the Chinese series as compared with the Scottish series, but the acid output per unit parietal cell mass (MAO per $10^{9}$ parietal cells) was not different in the two groups. These observations suggested that the Chinese patients with duodenal ulcer had smaller parietal cell mass compared with the Westerners.

Using a 'standard' dose of histamine acid phosphate $(0.04 \mathrm{mg} / \mathrm{kg})$ as stimulus, the maximum acid output (MAO) of Indians (Vakil and Mulekar, 1965; Goyal et al., 1966; Desai et al., 1969) and Singaporean Chinese (Fung, 1970) was about half the values obtained in Occidentals, both with respect to normal subjects and patients with duodenal ulcer. The difference may be related in part to the doses of histamine acid phosphate used. In Indians weighing between $\mathbf{4 0}$ and $60 \mathrm{~kg}$, doses of histamine acid phosphate of 0.05 $\mathrm{mg} / \mathrm{kg}$ for normal subjects and $0.06 \mathrm{mg} / \mathrm{kg}$ for duodenal ulcer patients were required for maximal stimulation (Desai et al., 1969), while in Singaporean Chinese the equivalent dose was found to be 0.06 $\mathrm{mg} / \mathrm{kg}$ (Fung, 1970). Under such maximal stimulation, the Indians but not the Singaporean Chinese in these studies achieved a maximum acid output which was comparable with that of the Westerners. The possibility remains that Chinese may possess a smaller parietal cell mass as compared with the Occidentals.

Pentagastrin, at a dose of $6 \mathrm{ug} / \mathrm{kg}$, gives a 'maximal' acid secretion that is indistinguishable from a standard dose of histamine acid phosphate (Multicentre Pilot Study, 1967; Desai et al., 1970) and

Received for publication 15 March 1977 because of its safety has been regarded as the stimulant of choice (Baron, 1970).

In this study, the effect on acid secretion after a standard dose of pentagastrin was compared with doses of $9 \mathrm{ug} / \mathrm{kg}$ and $12 \mathrm{ug} / \mathrm{kg}$ in a series of Chinese patients with duodenal ulcer and controls. In addition, the parietal cell mass of a group of duodenal ulcer subjects was estimated and correlated with their corresponding MAO.

\section{Methods}

MAXIMUM ACID OUTPUT

Sixty-eight patients with duodenal ulceration proven by barium studies, endoscopy, and/or subsequent surgery were studied. In 24 patients the MAO in the hour after subcutaneous doses of $6 \mathrm{ug} / \mathrm{kg}$ and $9 \mathrm{ug} /$ $\mathrm{kg}$ of pentagastrin was measured, and in 44 MAO was estimated after doses of $6 \mathrm{ug} / \mathrm{kg}$ and $12 \mathrm{ug} / \mathrm{kg}$. Twenty-two healthy subjects acted as controls. Their MAO was measured after doses of $6 \mathrm{ug} / \mathrm{kg}$ and $9 \mathrm{ug} / \mathrm{kg}$ pentagastrin.

The procedure of estimating MAO was conventional (Baron, 1973). In all cases, the nasogastric tube was positioned fluoroscopically. Care was taken that drugs, particularly anticholinergics, were withdrawn before the tests. Smoking was prohibited 
during the tests and the subjects were encouraged to spit out the saliva and not to swallow it. No attempt was made to measure the loss of gastric juice through the pylorus nor to prevent duodenogastric reflux. In each individual, the tests with the standard and higher doses of pentagastrin were performed on separate days and the order of the tests was randomised. No side-effect was observed in any subject.

MEASUREMENT OF PARIETAL CELL MASS

Twelve of the patients with duodenal ulcer underwent partial gastrectomy with the Polya Hofmeister type of anastomosis. In each case the MAO test was repeated two weeks after surgery.

The parietal cell mass was estimated using the method of Card and Marks (1960).

\section{STATISTICAL METHOD}

The $t$ test for paired and unpaired data and Chi square test where appropriate were used. Where possible comparison of the means of two groups of MAO was by Wilcoxon's non-parametric test (Diem and Lentner, 1970).

\section{Results}

MAXIMUM ACID OUTPUT (MAO)

There was no significant difference in MAO using

Table 1 Maximum acid output (MAO) to $6 \mathrm{ug} / \mathrm{kg}$ and $9 \mathrm{ug} / \mathrm{kg}$ pentagastrin in healthy subjects

\begin{tabular}{|c|c|c|c|c|c|}
\hline & \multirow[t]{2}{*}{ No. } & \multirow{2}{*}{$\begin{array}{c}\text { Age } \\
(y r)\end{array}$} & \multirow{2}{*}{$\begin{array}{l}\text { Body weight } \\
(k g)\end{array}$} & \multicolumn{2}{|c|}{$M A O(\mathrm{mmol} / \mathrm{h})$} \\
\hline & & & & 6 ug/kg & $9 u g / k g$ \\
\hline $\begin{array}{l}\text { Male } \\
\text { Female }\end{array}$ & 13 & $\begin{array}{c}44 \cdot 4^{\mathrm{a}} \\
\pm 13 \cdot 5 \\
46 \cdot 3^{\mathrm{b}} \\
\pm 17 \cdot 1\end{array}$ & $\begin{array}{c}51 \cdot 1^{c} \\
\pm 6 \cdot 1 \\
48 \cdot 3^{d} \\
\pm 6 \cdot 5\end{array}$ & $\begin{array}{c}10 \cdot 6^{1} \\
\pm 5 \cdot 7 \\
9 \cdot 6^{2} \\
\pm 4 \cdot 1\end{array}$ & $\begin{array}{r}10.1^{2} \\
+4.0 \\
10.9 \\
\pm \quad 4.8\end{array}$ \\
\hline
\end{tabular}

Mean \pm SD. NS = not significant.

1 and 27

$\left.\begin{array}{l}3 \text { and } 4 \\ 1 \text { and } 3\end{array}\right\} N S_{c \text { and } d}^{a}$ and $b N S$

2 and 4 doses of $6 \mathrm{ug} / \mathrm{kg}$ pentagastrin in the normal subjects (Table 1) and the patients with duodenal ulcer irrespective of sex (Table 2). Similarly no difference was observed in the duodenal ulcer patients when doses of $6 \mathrm{ug} / \mathrm{kg}$ and $12 \mathrm{ug} / \mathrm{kg}$ pentagastrin were used (Table 2). In both sexes the mean MAO of duodenal ulcer patients was significantly higher than the controls (Table 3). The age and body weight of all groups compared were comparable (Tables $1,2,3)$.

Table 3 Maximum acid output (MAO) to $6 \mathrm{ug} / \mathrm{kg}$ pentagastrin in Chinese patients with duodenal ulcer and controls

\begin{tabular}{|c|c|c|c|c|c|}
\hline & & No. & $\begin{array}{l}\text { Age } \\
(y r)\end{array}$ & $\begin{array}{l}\text { Body weight } \\
(k g)\end{array}$ & $\begin{array}{l}M A O \\
(\mathrm{mmol} / \mathrm{h})\end{array}$ \\
\hline Duodenal ulcer & $\begin{array}{l}\text { Male } \\
\text { Female }\end{array}$ & $\begin{array}{l}49 \\
19\end{array}$ & $\begin{array}{c}45.5^{\mathrm{a}} \\
\pm 13.2 \\
49.9 \mathrm{~b} \\
\pm 11.4\end{array}$ & $\begin{array}{c}54.8^{\mathrm{c}} \\
\pm 10 \cdot 7 \\
50.5^{\mathrm{d}} \\
5.9\end{array}$ & $\begin{array}{c}22 \cdot 7^{\circ} \\
\pm 7 \cdot 4 \\
21 \cdot 3^{\circ} \\
\pm 6.5\end{array}$ \\
\hline Normal & $\begin{array}{l}\text { Male } \\
\text { Female }\end{array}$ & $\begin{array}{l}19 \\
13\end{array}$ & $\begin{array}{c}44 \cdot 4^{\mathrm{a}} \\
\pm 13 \cdot 5^{\circ} \\
46 \cdot 3^{\mathrm{b}} \\
\pm 17 \cdot 1\end{array}$ & $\begin{array}{c}51 \cdot 1^{c} \\
\pm 6 \cdot 1 \\
48 \cdot 4^{d} \\
\pm 6.5\end{array}$ & $\begin{array}{c}10.6^{\circ} \\
+5.7 \\
9.6^{\circ} \\
\pm 4.1\end{array}$ \\
\hline
\end{tabular}

Mean \pm SD. NS $=$ not significant.

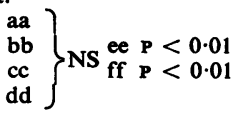

A significant correlation between MAO and body weight was observed in the normal subjects and the patients with duodenal ulcer (Fig. 1).

COMPARISON WITH OTHER SERIES (Table 4) It can be appreciated that a gross difference is present between the Western series and the Chinese series, the latter being fairly comparable with the other Asian series. Because of variation in the way of expressing acid output, because the doses of stimulants used in some studies would give only submaximal effect, and because of the failure in some reports to subdivide patients according to sex, statistical comparison with the Hong Kong series was deemed legitimate only in the two Edinburgh series, both

Table 2 Maximum acid output (MAO) to $6 \mathrm{ug} / \mathrm{kg}$ pentagastrin compared with 9 ug/kg and 12 ug/kg in Chinese patients with duodenal ulcer

\begin{tabular}{|c|c|c|c|c|c|c|c|c|c|c|}
\hline & \multirow[t]{2}{*}{ No. } & \multirow{2}{*}{$\begin{array}{l}\text { Age } \\
(y r)\end{array}$} & \multirow{2}{*}{$\begin{array}{l}\text { Body weight } \\
(k g)\end{array}$} & \multicolumn{2}{|c|}{$M A O(\mathrm{mmol} / \mathrm{h})$} & \multirow[t]{2}{*}{ No. } & \multirow{2}{*}{$\begin{array}{l}\text { Age } \\
(y r)\end{array}$} & \multirow{2}{*}{$\begin{array}{l}\text { Body weight } \\
(k g)\end{array}$} & \multicolumn{2}{|c|}{$M A O(\mathrm{mmol} / \mathrm{h})$} \\
\hline & & & & $6 \mathrm{ug} / \mathrm{kg}$ & 9 ug/kg & & & & $6 \mathrm{ug} / \mathrm{kg}$ & $12 \mathrm{ug} / \mathrm{kg}$ \\
\hline
\end{tabular}

Mean \pm SD. NS $=$ not significant.

1 and 27

3 and 4

5 and 6$\}$ NS

7 and 8

$\left.\begin{array}{l}1 \text { and } 3 \\ 2 \text { and } 4 \\ 5 \text { and } 7 \\ 6 \text { and } 8\end{array}\right\} N$

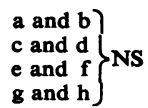




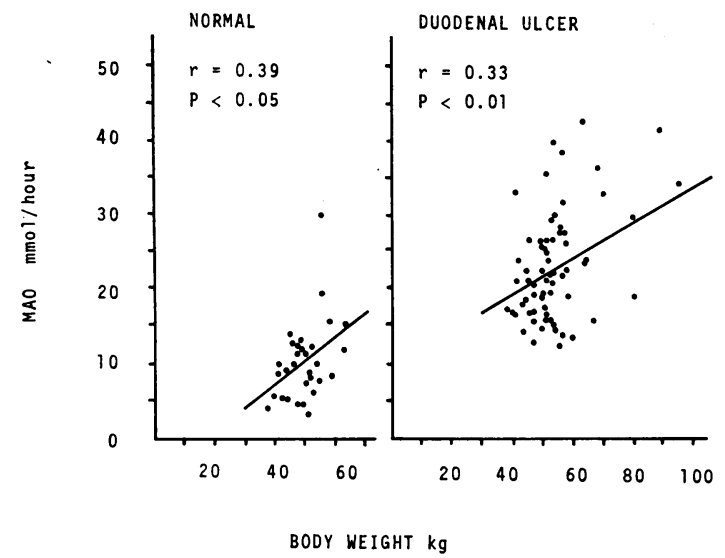

Fig. 1 Relation between maximum acid output $(M A O)$ and total body weight in Chinese normal subjects and patients with duodenal ulcer.

showing significant differences from the Hong Kong series.

Furthermore, it was possible to compare the present series with the Scottish series of ulcer patients reported by Lam and Sircus (1975) with respect to the MAO in relation to body weight. The Scottish patients had longer ulcer histories and were heavier. Their MAO in $\mathrm{mmol} / \mathrm{h} / \mathrm{kg}$ body weight was significantly higher than that of the Chinese patients in the male subjects but not so in the female subjects(Table 5). The insignificant difference between the females of the two races is most likely due to the small number of Chinese females in this study.

PARIETAL CELL MASS

In 12 duodenal ulcer patients, the differences in MAO before and after gastrectomy were correlated with the parietal cell counts as estimated from the resected portions of the 12 stomachs. A significant correlation was observed (Fig. 2).

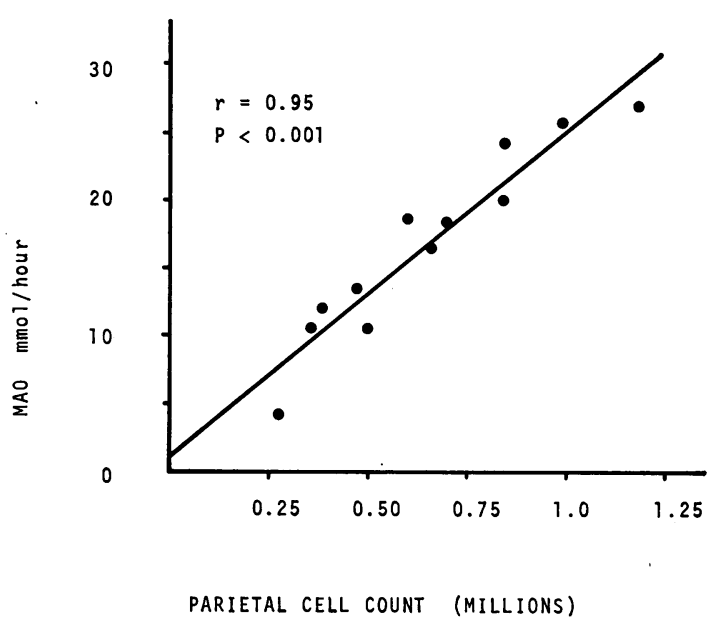

Fig. 2 Relation between maximum acid output and parietal cell mass calculated for the resected stomachs of 12 Chinese patients with duodenal ulcer.

Table 4 Maximum acid output (mmol/hour) ${ }^{1}$ in the present study, in other Asian countries and in Western countries

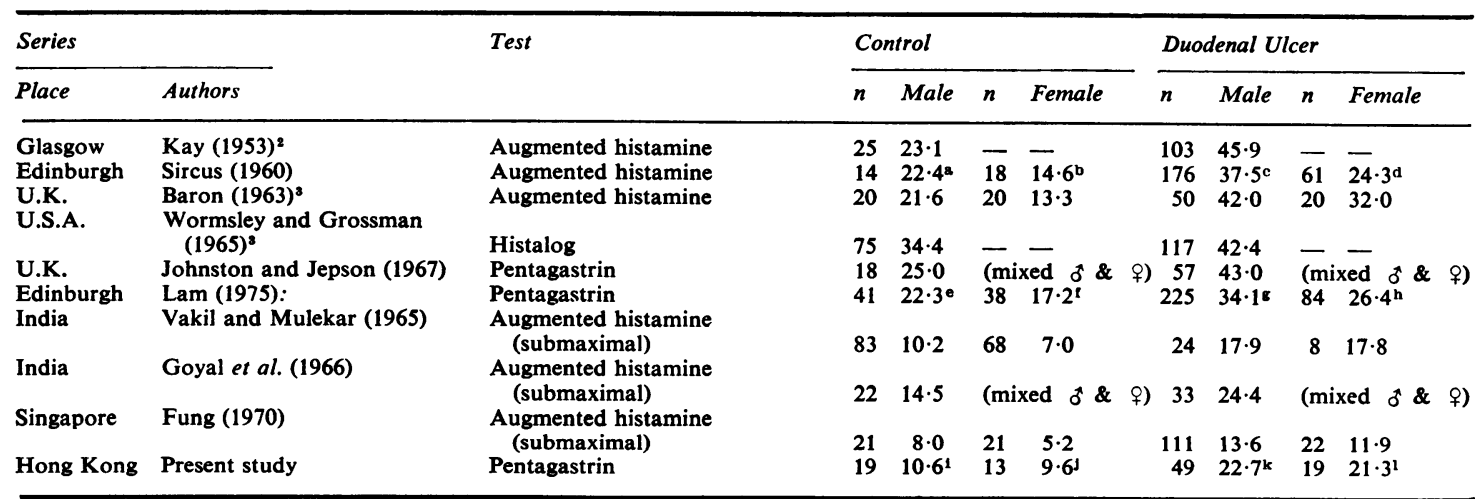

1 Mean values only are listed.

2 Results obtained by converting $\mathrm{mg} \mathrm{HCl} / 30 \mathrm{~min}$ to $\mathrm{mmol} / \mathrm{h}$.

3 Peak acid output (i.e. peak $30 \mathrm{~min}$ output $\times 2$ ).

$i$ and $a \quad P<0.0005$

$\mathrm{j}$ and $\mathrm{b} \quad \mathrm{P}<0.01$

$k$ and $c \quad P<0.0005$

1 and $d$ not significant

1 and $h \quad P<0.01$ 
Table 5 Comparison of maximum acid output $(M A O)$, in relation to body weight, age, and duration of ulcer symptoms between the present series of ulcer patients and a Scottish series*

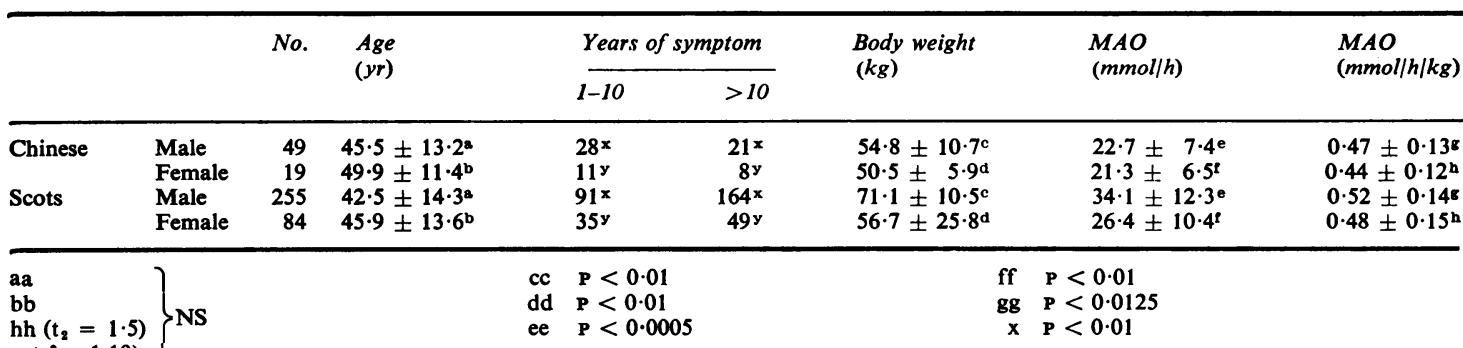

$\mathrm{y}\left(\mathrm{x}^{2}=1 \cdot 10\right)$

Mean \pm SD. NS $=$ not significant.

*As reported by Lam and Sircus (1975).

The MAO and the parietal cell mass of the Chinese patients were compared with those of the Scottish patients reported by Card and Marks (1960), and were found to be significantly smaller. The acid output per unit parietal cell mass, however, was not different (Table 6).

\section{Discussion}

We have found that increasing the dosage of pentagastrin from the standard dose of $6 \mathrm{ug} / \mathrm{kg}$ to either 9 $\mathrm{ug} / \mathrm{kg}$ or $12 \mathrm{ug} / \mathrm{kg}$ does not result in a further rise or fall in maximum acid output (MAO) in Chinese subjects, normal or with duodenal ulcer. This agrees with the observation of a multicentre study (Multicentre Pilot Study, 1967) in six subjects that the acid output to doses of $6 \mathrm{ug} / \mathrm{kg}$ and $9 \mathrm{ug} / \mathrm{kg}$ was not significantly different. Although we have not tested whether doses less than $6 \mathrm{ug} / \mathrm{kg}$ will produce similar maximal effects on acid secretion, $6 \mathrm{ug} / \mathrm{kg}$ pentagastrin appeared to be a safe and suitable standard dose for Chinese subjects.

Previous studies of the MAO in Indians (Vakil and Mulekar, 1965; Goyal et al., 1966) and in Singaporean Chinese (Fung, 1970), both however using a submaximal dose of histamine acid phosphate (vide supra), suggest that the Asians, normal and with duodenal ulcer, have a smaller acid output when compared with the reported series of Occidental subjects. The present study, in which a maximal dose of pentagastrin is used, reveals similar findings (Table 4) and further supports the concept that the Asians have smaller MAO. There are several possible explanations.

Firstly, since MAO is a reflection of parietal cell mass, as indicated by the original findings of Card and Marks (1960) as well as by the present study (Fig. 2), our findings would suggest that the Chinese possess a smaller parietal cell mass than the Occidentals. Comparison of the parietal cell counts on resected stomachs of duodenal ulcer patients as observed in this study with those observed by Card and Marks (Table 5) would further support this concept. Although the proportion of stomach resected obviously may vary, despite the fact that the same type of surgery was performed in both series (Polya Hofmeister), it would appear that the difference in counts in the two series is too gross to be explained by such variation. Furthermore, the acid output per unit parietal cell mass is not statistically different in the Scottish and Chinese patients (Table 5), strongly indicating that the smaller MAO of the Chinese patients is related to a smaller parietal cell mass.

Table 6 Comparison of acid secretion and parietal cell counts between Chinese and Scottish* patients with duodenal ulcer

\begin{tabular}{|c|c|c|c|c|c|}
\hline & No. & Pregastrectomy MAO (mmol/h) & $M A O \dagger(\mathrm{mmol} / \mathrm{h})$ & Parietal cell count (millions) & Acid output/u parietal cell mass $\ddagger$ \\
\hline $\begin{array}{l}\text { Chinese } \\
\text { Scots }\end{array}$ & $\begin{array}{l}12 \\
10\end{array}$ & $\begin{array}{c}19.9^{\mathrm{a}} \\
\pm \quad 6 \cdot 7 \\
49 \cdot 8^{\mathrm{a}} \\
\pm 23 \cdot 1\end{array}$ & $\begin{array}{c}16 \cdot 7^{b} \\
\pm \quad 6 \cdot 9 \\
40 \cdot 2^{b} \\
\pm 17 \cdot 7\end{array}$ & $\begin{aligned} & 654 \cdot 3^{c} \\
\pm & 275 \cdot 1 \\
1307 c & \\
\pm & 360\end{aligned}$ & $\begin{array}{c}25 \cdot 3^{d} \\
\pm 4 \cdot 5 \\
28 \cdot 0^{d} \\
\pm 4 \cdot 0 \\
(n=8)\end{array}$ \\
\hline
\end{tabular}

mean \pm SD. NS $=$ not significant.

$\left.\begin{array}{l}\text { a } \\ \text { c }\end{array}\right\} P<0.0005$

d $\quad N S(t=1 \cdot 35)$

*as reported by Card and Marks (1960).

†MAO = mean of differences in MAO before and after gastrectomy.

$\ddagger$ MAO (mmol/h) corresponding to $10^{\circ}$ parietal cells. 
Secondly, MAO is correlated with body weight both in normal subjects and in patients with peptic ulcer as observed in the present study (Fig. 1) and those of others (Baron, 1963; Novis et al., 1973). The smaller MAO in the present Chinese series therefore may be related in part to a smaller body weight. The mean body weight of $54.8 \mathrm{~kg}$ for males and $50.5 \mathrm{~kg}$ for females in the present series, as compared with the generally accepted average of $60-70 \mathrm{~kg}$ for the Westerners would lend some support to the idea. In fact, the body weight of the Chinese patients in this series is significantly smaller than the Scots as reported in an Edinburgh series (Table 5). It was observed that expressing MAO in $\mathrm{mmol} / \mathrm{hour} / \mathrm{kg}$ total body weight in normal subjects eliminates the difference in MAO as expressed in $\mathrm{mmol} /$ hour in the two sexes (Lam and Sircus, 1975), as well as the difference in two ethnic groups (Lam, 1975). Expressed in this manner the MAO of the Scottish male patients is still significantly larger, albeit less so than that of the Chinese male patients, but not so with respect to the female patients. Furthermore, MAO has been found to relate to body height (Hobsley et al., 1975), a factor which the present study is unable to examine. We believe that size is an important factor in explaining the racial difference in MAO.

Thirdly, MAO appears to decrease in the aged (Baron, 1963; Grossman et al., 1963). As the number of patients in this series is not large enough to give a meaningful result on statistical analysis with respect to increasing age, the effect of age on acid output in the Chinese subject has not been defined. However, age is unlikely to be an important factor, as the mean age in the two sexes in the present series is not appreciably different from that in a Scottish series (Table 4).

Fourthly, acid secretion in duodenal ulcer patients has been found to be related to the length of ulcer history (Sircus, 1968; Lam and Sircus, 1975; Hobsley et al., 1975). Comparison of the present series with the Scottish series indeed shows that the patients in the Scottish series have a longer duration of symptoms compared with the Chinese patients and may thus explain in part their possession of a larger MAO.

Fifthly, among the duodenal ulcer population, there is always a group in whom the MAO is within the range of normality and a group whose MAO is above this range (Baron, 1970). Expressing MAO in relation to body weight, the proportion of hypersecretors in a Scottish series has been found to be approximately $50 \%$ (Lam and Sircus, 1975), whereas that in a Chinese series is approximately $30 \%$ (Lam et al., unpublished data). Thus a random sample of Chinese duodenal ulcer patients would have a mean MAO which is smaller than that of a random series of Scottish patients, as there will be more normosecretors in the former and more hypersecretors in the latter. This may be an important factor in accounting for the apparent discrepancy in MAO between Chinese and Occidentals.

In conclusion, we have shown that $6 \mathrm{ug} / \mathrm{kg}$ pentagastrin is a safe and maximal dose for measuring the MAO in Chinese normal subjects and patients with duodenal ulcer. We have found that the MAO of the Chinese patients with duodenal ulcer is appreciably smaller than that of the Occidentals and that this is most probably related to their possession of a smaller parietal cell mass.

\section{References}

Baron, J. H. (1963). Studies of basal and peak acid output with an augmented histamine test. Gut, 4, 136-144.

Baron, J. H. (1970). The clinical use of gastric function tests. Scandinavian Journal of Gastroenterology, suppl. 6, 9-46.

Baron, J. H. (1973). The clinical application of gastric secretion measurements. Clinics in Gastroenterology, vol. 2, pp. 293-314. Edited by W. Sircus. Saunders: Philadelphia.

Card, W. I., and Marks, I. N. (1960). The relationship between the acid output of the stomach following 'maximal' histamine stimulation and the parietal cell mass. Clinical Science, 19, 147-163.

Desai, H. G., Antia, F. P., Gupte, U. V., and Potnis, P. R. (1969). Dose of histamine for maximal stimulation of gastric acid secretion. Gastroenterology, 57, 636-640.

Diem, K., and Lentner, C. (eds) (1970). Documenta Geigy, p. 192. Geigy: Basle, Switzerland.

Fung, W. P. (1970). Gastric acid secretion in Chinese with particular reference to the dose of histamine required for maximal stimulation. Gut, 11, 955-961.

Goyal, P. K., Gupta, P. S., and Chuttani, H. K. (1966). Gastric acid secretion in Indians with particular reference to the ratio of basal to maximal acid output. Gut, 7, 619623.

Hobsley, M., Whitfield, P. F., Faber, R. G., and Parkin, J. V. (1975). Hypersecretion and length of history in duodenal ulceration. Lancet, 2, 101-104.

Johnston, D., and Jepson, K. (1967). Use of pentagastrin in a test of gastric acid secretion. Lancet, 11, 585-588.

Kay, A. W. (1953). Effect of large doses of histamine on gastric secretion of HC1. British Medical Journal, 11, 77-80.

Lam, S. K. (1975). Clinical and Pathophysiological Studies on Duodenal Ulcers: Evidence for the Existence of Two Populations. M.D. Thesis: University of Hong Kong.

Lam, S. K., and Sircus, W. (1975). Studies on duodenal ulcer I. Clinical evidence for the existence of two populations. Quarterly Journal of Medicine, 44, 369-387.

Multicentre Pilot Study (1967). Pentagastrin as a stimulant of maximal gastric acid response in man. Lancet, 1, 291-294.

Novis, B. H., Marks, I. N., Banks. S., and Sloan, A. W. (1973). The relationship between gastric acid secretion and body habitus, blood groups, smoking, and the subsequent development of dyspepsia and duodenal ulcer. Gut, 14, 107112.

Sircus, W. (1960). The aetiology of peptic ulcer. In Peptic Ulcer: a Symposium for Surgeons, pp. 11-36. Edited by C. Wells and J. Kyle. Livingstone: Edinburgh.

Sircus, W. (1968). Gastric secretion in peptic ulcer disease with special reference to the influence of body weight, duration of disease and stenosis. In Physiology of Gastric 
Secretion, pp. 581-591. Edited by L. S. Semb, and I.Myren. Universitetsforlaget: Oslo.

Vakil, B. J., and Mulekar, A. M. (1965). Studies with the maximal histamine test. Gut, 7, 364-371.
Wormsley, K. G., and Grossman, M. I. (1965). Maximal histalog test in control subjects and patients with peptic ulcer. Gut, 6, 427-435.

\section{The September 1977 Issue}

\section{THE SEPTEMBER 1977 ISSUE CONTAINS THE FOLLOWING PAPERS}

Potassium and magnesium depletion in patients with cirrhosis on maintenance diuretic regimes P. G. WHEELER, T. SMITH, C. GOLINDANO, A. N. ALAM, S. P. WILKINSON, C. J. EDMONDS, AND ROGER WILLIAMS

Can hepatic coma be casued by a reduction of brain noradrenaline or dopamine? L. ZIEVE AND R. $L$. OLSEN

Serum, cerebrospinal fluid, and brain levels of bile acids in patients with fulminant hepatic failure B. BRON, R. WALDRAM, D. B. A. SILK, AND ROGER WILLIAMS

Assessment of the plasma disappearance of cholyl$1^{14} \mathrm{C}$-glycine as a test of hepatocellular disease $\mathrm{B}$. THJODIEIFSSON, S. BARNES, A. CHITRANUKROH, BARBARA H. BILLING, AND SHEILA SHERLOCK

Mechanism and specificity of increased amylase/ creatinine clearance ratio in pancreatitis $A$. MARTEN, D. BEALES, AND E. ELIAS

Postprandial gastro-oesophageal reflux in healthy people M. D. KAYE

Somatostatin therapy in acute experimental pancreatitis P. G. LANKISCH, H. KOOP, K. WINCKLER, U. R. FÖLSCH, AND W. CREUTZFELDT

Carbenoxolone sodium capsules in the treatment of duodenal ulcer. An endoscopic controlled trial J. SAHEL
Effect of carbenoxolone sodium on human gastric acid secretion J. H. BARON

Double-blind controlled trial of amylopectin sulphate (Depepsen) in the symptomatic treatment of duodenal ulcer J. H. BARON, R. J. N. GRIBBLE, D. J. HOLDSTOCK, AND J. J. MISIEWICZ

Gastric emptying of wholemeal and white bread D. S. GRIMES AND J. GODDARD

Bile acid studies in uncomplicated Crohn's disease G. VANTRAPPEN, Y. GHOOS, P. RUTGEERTS, AND J. JANSSENS

${ }^{14} \mathrm{C}$-glycocholate test in Crohn's disease-its value in assessment and treatment J. H. B. SCARPELLO AND G. E. SLADEN

Appraisal of the ${ }^{14} \mathrm{C}$-glycocholate acid test with special reference to the measurement of faecal ${ }^{14} \mathrm{C}$ excretion J. H. B. SCARPELLO AND G. E. SLADEN

Humoral immune system in inflammatory bowel disease: I. Complement levels H. J. F. HODGSON, B. J. POTTER, AND D. P. JEWELL

Adynamic bowel syndrome. Report of a case with disturbance of the cholinergic innervation P. PURI, B. D. LAKE, AND H. H. NIXON

Progress report Non-surgical removal of common bile duct stones M. CLASSEN AND F. W. OSSENBERG

Notes and activities

Books

Copies are still available and may be obtained from the PUBLISHING MANAGER, BRITISH MEDICAL ASSOCIATION, TAVISTOCK SQUARE, WC1H 9JR, price $£ 2.75$, including postage 